\title{
Finite Element Analysis of Counterbore-shaped Parts by Using Sheet-bulk Metal Forming Process
}

\author{
Sutasn Thipprakmas ${ }^{1}$, Arkarapon Sontamino ${ }^{2}$, and Wiriyakorn Phanitwong \\ ${ }^{1}$ Department of Tool and Materials Engineering, King Mongkut's University of Technology Thonburi, Thailand, E- \\ mail: sutasn.thi@kmutt.ac.th, wiriyakorn.wp@gmail.com \\ ${ }^{2}$ Graduate student, Dept. of Tool and Materials Engineering, King Mongkut's University of Technology Thonburi, \\ Bangkok, Thailand
}

The merits of metal-forming process, as compared to the material removal process, are a good utilization of material and shorten the production time. To fabricate the complex shaped parts, it is increasingly applied. As a particular type of metal-forming process, to produce counterbore-shaped parts, the sheet-bulk metal forming which controls the flow of material into special punch and die was investigated in the present study. The finite element method (FEM) was used as a tool to investigate the sheet-bulk metal forming mechanism and their defects occurred during process. The sheet-bulk metal forming mechanism and poor squareness defect were clearly identified via the changes of the material flow and stress distribution analyses. In addition, the relationships between forged punch diameter and limitation of material thickness and hole diameter changes after forging were also investigated. Laboratory pressing experiments were performed to validate the accuracy of the FEM simulation results. The FEM simulation results showed good agreement with the experimental results with regards to the dimensions of the cut surface in the punching operation and counterbore shape in the sheet-forging operation.

Keywords: Sheet-bulk metal forming; Sheet-forging; Punching; Counterbore; Finite Element Analysis

\section{Acknowledgements}

This research was partially supported by a Grant from the Thai-German Institute (TGI) under Grant No. S2-CD03/2554 and the Higher Education Research Promotion and National Research University Project of Thailand, Office of the Higher Education Commission, under Grant No. 56000519 and Grant No. 57000618. The authors would also like to thank Mr. Pakkawat Komolruji for his assistance during this study.

\section{References}

[1] CHEN, Z. H., TANG, C. Y., CHAN, L. C. et al. (1999). Simulation of the sheet extrusion process by the enhanced assumed strain finite element method, J. Mater. Process Technol. 91:250-256.

[2] CHEN, F. K., HUANG, T. B., WANG, S. J. (2007). A study of flow-through phenomenon in the press forging of magnesium-alloy sheets, J. Mater. Process. Technol. 187-188:770.

[3] GHASSEMALI, E., TAN, M. J., JARFORS, A. E. W. et al. (2013). Optimization of axisymmetric open-die microforging/extrusion processes: An upper bound approach, Int. J. Mech. Sci. 71:58-67.

[4] GONTARZ, A., PIESIAK, J. (2015). Determining the Normalized Cockroft-Latham Criterion for Titanium Alloy Ti6Al4V in Tensile Testing At Room Temperature, Proceedings of Proceedings of the World Congress on Mechanical, Chemical, and Material Engineering (MCM 2015), pp. 248 (1-4), International ASET Inc.

[5] HIROTA, K. (2007). Fabrication of micro-billet by sheet extrusion, J. Mater. Process. Technol. 191:283-287.

[6] JENÍČEK, S., VOREL, I., KÁŇA, J., OPATOVÁ, K. (2017). The use of material-technological modelling to determine the effect of temperature and amount of deformation on microstructure evolution in a closed-die forging treated by controlled cooling, Manufacturing Technology, 17(3): 326-330.

[7] KALPAKJIAN, S., SCHMID, S. (2006). Manufacturing Engineering and Technology, Prentice Hall, Singapore, $6^{\text {th }}$ edition.

[8] LANGE, K., (1985). Handbook of metal forming. McGraw-Hill Inc., New York.

[9] LOU, S., WANG, Y., LU, S., SU, C. (2016). Extrusion process parameters optimization for the aluminum profile extrusion of an upper beam on the train based on response surface methodology, Manufacturing Technology, 16(3): 551-557.

[10] PHANITWONG, W., THIPPRAKMAS, S. (2015). Finite element analysis of piping defect formation in the sheetextrusion process, Int. J. Model. Simul. Sci. Comput. 6(1): 1550010 (10 pages)

[11] SCHULER (1998). Metal forming handbook. Springer, Berlin. 
[12] THIPPRAKMAS, S., ROJANANAN, S., PARAMAPUTI, P. (2008). An investigation of step taper-shaped punch in piercing process using finite element method. J Mater Process Technol. 197:132-139.

[13] THIPPRAKMAS, S., PHANITWONG, W. (2010). Finite element analysis of shaving direction effects in reciprocating shaving process, Steel Res Int. 81(9), 1058-1061.

[14] THIPPRAKMAS, S., PHANITWONG, W. (2012). Finite element analysis of flange-forming direction in the hole flanging process, Int $J$ Adv Manuf Tech. 61(5), 609-620.

[15] ZHENG, P. F., CHAN, L. C., LEE, T. C. (2005). Numerical analysis of the sheet metal extrusion, Finite Elem. Anal. Des. 42:189-207.

[16] ZHUANG, X. C., ZHAO, Z., XIANG, H. et al. (2008). Simulation of sheet metal extrusion processes with arbitrary Langrangian-Eulerian method, Trans. Nonferrous Met. Soc. China 18:1172-1176.

Copyright (C) 2017. Published by Manufacturing Technology. All rights reserved. 